\title{
Onko lajikkeella väliä, parsakaalin lajikevalinta ja aistittava laatu
}

\author{
Marja Kallela $^{1)}$, Sanna Lehtonen ${ }^{1,2)}$ ja Tiina Peltue ${ }^{1,2)}$ \\ ${ }^{1)}$ Maa ja Elintarviketalouden tutkimuskeskus (MTT), Puutarhatuotanto, Toivonlinnatie 518, 21500 Piik- \\ kiö, marja.kallela@mtt.fi \\ ${ }^{2)}$ Hämeen ammattikorkeakoulu, Lepaa, Lepaantie 129, 14610 Lepaa
}

\section{Tiivistelmä}

Parsakaalin (Brassica oleracea var. italica) viljely ja tuotanto ovat lisääntyneet Suomessa 1990-luvulta alkaen voimakkaasti uusien, tasaisemmin satoa tuottavien lajikkeiden ja sadon ajoituksen takia. Lisäksi kuluttajat ovat oppineet käyttämään terveellistä ja maukasta kaalia monipuolisemmin. Ammattiviljelyssä lajikevalinta on haastava tehtävä varsinkin luomutuotantojärjestelmässä siksi, että aina ei ole saatavilla luomulisäysaineistoa tai tavanomaisesti tuotettuja käsittelemättömiä siemeniä. Hyvissä kasvuoloissa parsakaalit kasvavat helposti liian suuriksi. Tiheämmällä istutuksella ja vähäisemmällä typpilannoituksella saadaan kaalien kokoa rajoitettua jonkin verran. Lajikevalinta vaikuttaa sadon määrään sekä ulkoiseen ja aistittavaan laatuun. Tämän tutkimuksen tarkoituksena oli selvittää lajikevalinnan vaikutuksia parsakaalin ulkoiseen ja aistittavaan laatuun. Lisäksi tarkasteltiin kasvuston katteen vaikutusta tavanomaisen ja luomu viljelyjärjestelmän mukaan tuotetun parsakaalin laatuun.

Useimpien lajikkeiden sadosta oli yli 90 prosenttia kauppakelpoista vuonna 2004, jolloin kasvukausi oli kaalin viljelylle sopiva sateinen ja viileä. Seuraavana vuonna kasvukausi oli myös sateinen, mutta heinäkuussa oli hellettä ja kosteaa. Silloin kauppakelpoista satoa alensivat kosteassa ja lämpimässä viihtyvät bakteeritaudit.

Aistinvaraisissa arvioissa kauppakelpoisesta vuoden 2005 sadosta elokuun alussa kerätyt lajikkeet olivat tummemman vihreitä kuin myöhemmin kerätyt lajikkeet. Vaikka 'Fellow'-lajikkeen ulkomuoto ei ollut tavoiteltu kupera, se oli aistinvaraisesti rakenteeltaan ja maultaan erittäin hyvä. Maultaan heikoimpia lajikkeita olivat Milady ja Triathlon. Eri kasvupaikkojen välillä oli eroja. Makuun ei kuitenkaan näyttäisi vaikuttavan viljelyjärjestelmä luomutuotannon eduksi, vaikka luomutuotetut kaalit olivat tässä tutkimuksessa aistinvaraisesti parempia kuin kokeen tavanomaisesti tuotetut kaalit. Tavanomaisesti tuotettu verrannekaali oli aistinvaraisesti samaa luokkaa luomukaalien kanssa.

Vuonna 2005 luomuviljelyssä hyväksi tuholaistentorjuntakeinoksi havaittu kasvuston kateharso ei vioittanut kaalien laatua. Harson alla kasvaneet kaalit olivat laadultaan hyviä, ellei parempiakin kuin ilman harsoa kasvatetut kaalit kuumuudesta huolimatta. Varmoja säänkestäviä lajikkeita voisivat olla esimerkiksi Montop ja Ironman lajikkeiden kaltaiset vaihtoehdot. Parsakaalikokeiden tulokset osoittavat, että ammattituotantoon tarkoitetuilla lajikkeilla ja luomumenetelmillä voidaan tuottaa erinomaisia parsakaaleja niin kooltaan kuin laadultaan.

\section{Asiasanat}

parsakaali, Brassica oleracea var. italica, aistinvarainen arvio, laatu, maku, luomu

\section{Johdanto}

Parsakaalin (Brassica oleracea var. italica) viljely ja tuotanto ovat lisääntyneet Suomessa 1990-luvulta alkaen voimakkaasti (Aaltonen 2005) uusien, tasaisemmin satoa tuottavien lajikkeiden ja sadon ajoituksen takia. Lisäksi kuluttajat ovat oppineet käyttämään terveellistä ja maukasta kaalia monipuolisemmin. Ammattiviljelyssä lajikevalinta on haastava tehtävä varsinkin luomutuotantojärjestelmässä siksi, että aina ei ole saatavilla luomulisäysaineistoa tai tavanomaisesti tuotettuja käsittelemättömiä siemeniä. Tämä tuli esille myös tämän maa- ja metsätalousministeriön rahoittaman hankkeen lajikekokeissa toisena vuonna, kun edellisvuoden verranteena ollutta Alborada-lajikkeen viljelyyn soveltuvaa siementä ei ollut saatavilla seuraavana vuonna. 
Hyvissä kasvuoloissa parsakaalit kasvavat helposti liian suuriksi, lähes kilon painoisiksi. Tiheämmällä istutuksella ja vähäisemmällä typpilannoituksella saadaan kaalien kokoa rajoitettua jonkin verran. Lajike vaikuttaa sadon kokoon ja laatuun. Parsakaalin kauppaan menevä tavoitekoko vaihtelee eri tuotteissa. Aikaisemmin tavoiteltiin yksittäispakkauksiin 250 gramman painoisia kaaleja, mutta nyt ovat yleistyneet myös 400 gramman yksittäispakatut tuotteet. Lisäksi myydään kaupalle edelleen suurempia eriä erillispakkaamatonta parsakaalia esimerkiksi viiden kilogramman erissä, joista kuluttajat valitsevat itse mieleisensä kaalin. Lajikevalinta vaikuttaa paitsi sadon määrään myös ulkoiseen ja aistittavaan laatuun. Tämän tutkimuksen tarkoituksena oli selvittää lajikevalinnan vaikutuksia parsakaalin ulkoiseen ja aistittavaan laatuun. Lisäksi selvitettiin kasvuston katteen vaikutusta tavanomaisen ja luomu viljelyjärjestelmän mukaan tuotetun parsakaalin laatuun.

\section{Aineisto ja menetelmät}

Lajikekokeet tehtiin Lepaan koulutilalla Hattulassa ja Vehnämäen tilalla Hauholla. Kokeissa vuosina 2004-2005 oli käytössä tavanomaiseen viljelyyn tarkoitettuja peittaamattomia siemeniä, jotka kylvön yhteydessä peitattiin Mycostop-sädesienivalmisteella. Näin saatiin torjuttua taimikasvatuksessa mahdollisesti ilmitulevia haitallisia tauteja, joita vähennetään tavanomaisessa viljelyssä mm. tiraamipeittauksella. Mukana olleet lajikkeet ovat esitettynä taulukossa 1. Vuonna 2004 luomujärjestelmän mukaan viljellyt parsakaalit istutettiin kesäkuun alussa neljänä toistona (Koe 1) Hauholle (1.6.) ja Hattulassa (2.-3.6.) noin kolme viikkoa vanhoilla taimilla, jotka oli kasvatettu Piikkiön tutkimuskasvihuoneissa. Osa lajikkeiden siemenistä saatiin vasta myöhemmin, joten kokeissa oli myös toinen istutusaika 21.-22.6. (Koe 2). Verrannelajikkeena oli Alborada, jota viljellään yleisesti sekä tavanomaisesti että luomuna. Lannoitteena oli molemmilla koepaikoilla kuorihumuskananlantakomposti, jolloin kokonaistypen määräksi tuli $170 \mathrm{~kg} / \mathrm{ha}$. Taimitiheys oli $40 \mathrm{~cm}$ ja riviväli $50 \mathrm{~cm}$. Kummankin kokeen ympärille istutettiin yksi rivi kiinankaalia houkuttelemaan kirppoja ja kaalikärpäsiä. Muuten lohkolla oli viljelijän omia talousvihanneksia. Kokeet peitettiin heti istutuksen jälkeen kasvuharsolla molemmilla paikoilla Hattulassa 6.7. ja Hauholla 9.7. asti. Maalaji oli Hauholla hikevä hieta ja Hattulassa hietainen savi. Hattulassa oli tiedossa viljelyhistorian perusteella, että luomuvihannesmaalla saattaa esiintyä möhöjuurta, joka sateisena kesänä tulisi esiin. Sadonkorjuu aloitettiin Hauholla 21. 7. ja Hattulassa 23.7. Viimeinen lajike korjattiin 20.8. kummaltakin koepaikalta. Kustakin lajikkeesta otettiin 84 parsakaalia. Ne leikattiin 16 - 20 senttimetrin mittaisiksi sopusuhtaisiksi kaaleiksi, jotka lajiteltiin kauppakelpoiset kaalit eri kokoluokkiin ja kauppakelvottomat erikseen.

Vuonna 2005 Hattulassa parsakaalit kasvatettiin tavanomaisen viljelyjärjestelmän mukaan ja Hauholla luomuna kuten vuonna 2004. Typpilannoitus tehtiin Hattulassa puutarhan Y1 lannoitteella kasvukauden alussa kokonaistyppimäärä $81 \mathrm{~kg} \mathrm{~N} / \mathrm{ha}$ ja heinäkuun lopussa $60 \mathrm{~kg} \mathrm{~N} / \mathrm{ha}$. Taimet istutettiin käsin 40 senttimetrin taimivälillä ja 50 sentin rivivälillä. Istutusaika oli myöhäinen; Hattulassa 21.6. ja Hauholla 22.6. Luomukokeessa koko kokeen ympärille istutettiin rivi kiinankaalia houkutuskasviksi pitämään tuholaiset poissa koealueelta. Lisäksi kasvuston yllä pidettiin istutuksen jälkeen kasvuharsoa noin viisi viikkoa. Harso otettiin pois rikkakasvien torjunnan yhteydessä 28.7. Kasvuharso oli päällä samaan aikaan kuin säät olivat lähes helteisiä ja useana päivänä tuo helleraja myös rikottiin. Hattulassa koetta ympäröivät talousviljelykset. Siellä ei tehty tuholaistorjuntoja ollenkaan, vaikka kasvustonkatetta ei ollut. Taimivaiheessa sadetettiin joitakin kertoja hyvän juurtumisen takaamiseksi. Sadonkorjuu aloitettiin 11.8. kolmella aikaisella lajikkeella kummaltakin koepaikalta. Viimeinen sadonkorjuu tehtiin 26.8. Sadonkorjuun yhteydessä arvioitiin kaalien kukinnon muotoa, nuppujen suuruutta ja väriä.

Taulukko 1. Parsakaalin lajikekokeen lajikkeet 2004-2005. Vuonna 20042 lajikenimen perässä tarkoittaa myöhempää istutusta (Koe 2) ja vuonna 2005 V lajikkeen perässä tarkoittaa, että lajike oli mukana vain Hauholla. 


\begin{tabular}{|c|c|}
\hline \multicolumn{2}{|c|}{ Parsakaali lajikkeet } \\
\hline 2004 & 2005 \\
\hline Triathlon & Triathlon \\
\hline Monterey & Monterey \\
\hline Alborada & Alborada V \\
\hline Lucky & Lucky \\
\hline Surveyor & Surveyor \\
\hline Montop & Montop \\
\hline Monaco & Monaco \\
\hline Milady2 & Milady \\
\hline Alborada2 & Fellow \\
\hline Iron2 & Ironman \\
\hline & Marathon \\
\hline
\end{tabular}

Vuonna 2004 tehtiin kahdesta lajikkeesta ja vuonna 2005 kaikista lajikkeista aistinvaraiset arviot Keskon tuotetutkimuksen laboratoriossa Helsingissä. Vuonna 2004 arviointityö tehtiin kolmihenkisessä asiantuntijaraadissa kahden viikon kuluttua sadonkorjuusta kolmessa erässä. Vuonna 2005 väri, rakenne, maku raakana ja maku kypsänä arviot teki sama asijantuntijaraati. Arviointi tehtiin 2-6 vuorokauden kuluttua sadonkorjuusta Karlsruhen asteikolla 9-1, jossa kauppakelpoisuuden rajana on 5. Verranteena oli yksittäispakattu tavanomaisesti viljelty Keskon 400 gramman Pirkka-parsakaali, joka oli arviointipäivänä menossa kauppaan. Kullekin arvioijalle annettiin näyte ainakin kahdesta eri kaalista. Näyte-erässä käytettiin neljästä kymmeneen kaalia kustakin lajikkeesta. Kypsennys tehtiin keittämällä kaalia vedessä kolme minuuttia.

\section{Tulokset ja tulosten tarkastelu}

Parsakaalilajikkeista aikaisin oli vuonna 2004 Montop, jonka sato kerättiin 50 - 51 vuorokauden kuluttua istutuksesta. Muiden lajikkeiden sato valmistui noin 61 vuorokauden kuluttua istutuksesta. Kukinnot olivat kauniin vihreitä, lukuun ottamatta Triathlonia, jonka kukinnot olivat kirjavia kuin kissansilmiä. Tämä johtui siitä, että kussakin haarassa nuput olivat erikokoisia; reunoilla pienempiä ja keskellä suurempia. Yleensä lajikkeiden kukinto oli kupera ja nuput korkeintaan nuppineulanpään kokoisia. Suurimmat nuput olivat Surveyor-lajikkeella. Lepaan parsakaalit olivat keskipainoltaan kevyempiä. Useimpien lajikkeiden sadosta oli yli 90 prosenttia kauppakelpoista (Kuvio 1). Kokeissa tavoitteena oli tuottaa keskipainoltaan vähintään $250 \mathrm{~g}$ kukintoja (Kuviot 2-3).

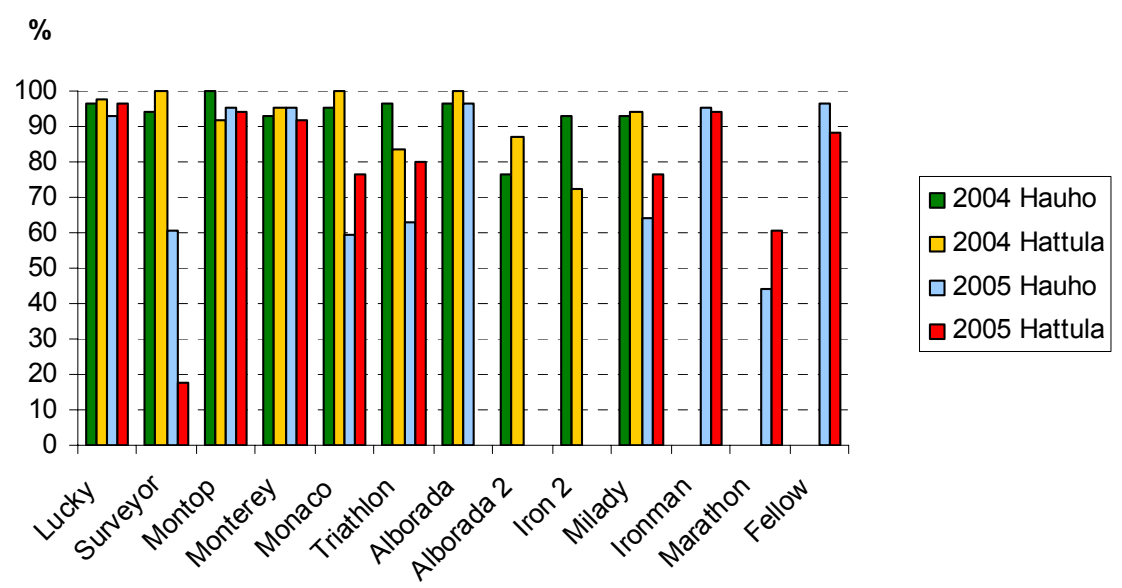

Kuvio 1. Kauppakelpoisen sadon osuus prosenttia kokonaissadosta eri lajikkeilla Hauholla ja Hattulassa vuosina 2004-2005. Numero 2 lajikenimen perässä tarkoittaa myöhempää istutusta (Koe 2). 


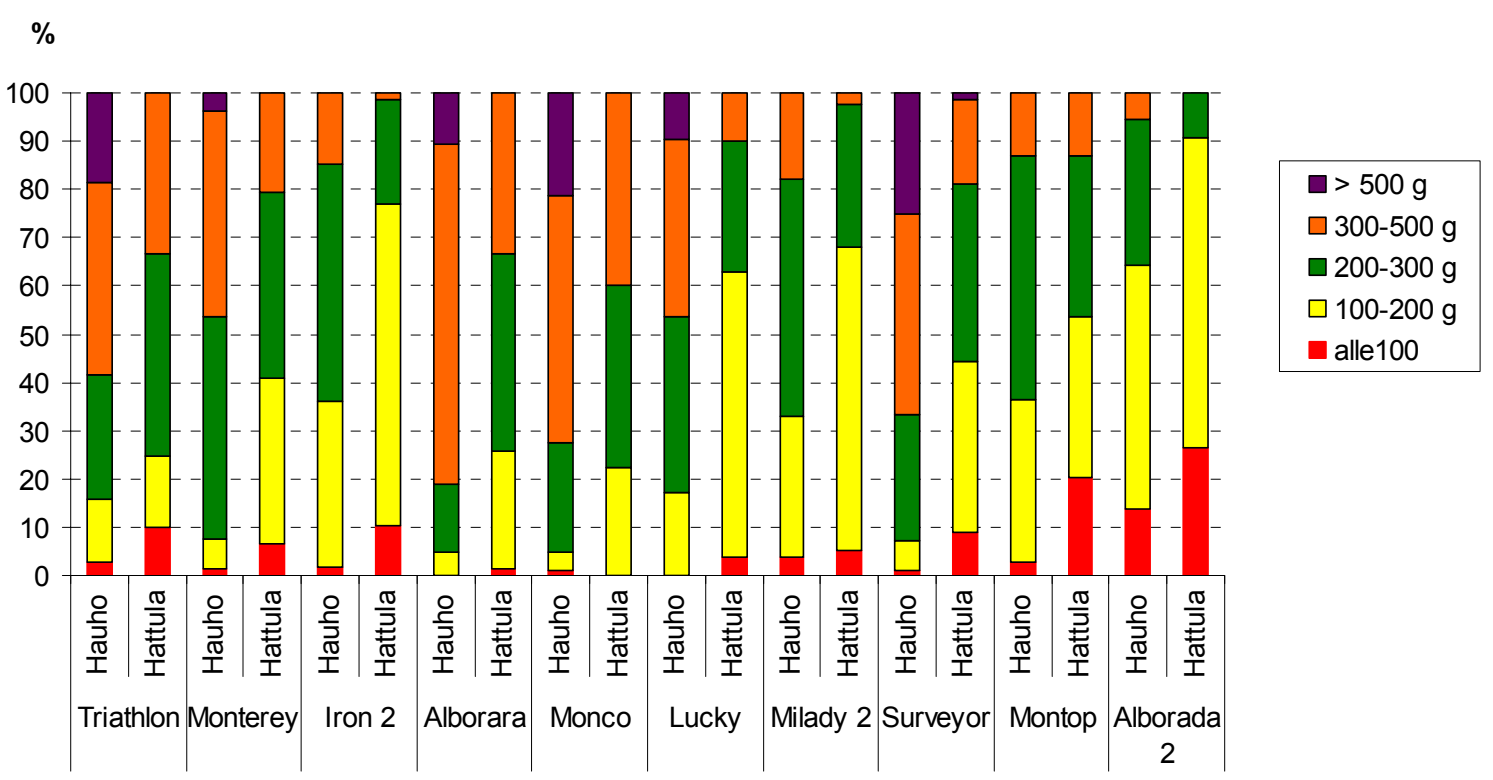

Kuvio 2. Parsakaalin kauppakelpoinen sato lajiteltuna eri kokoluokkiin vuonna 2004. Numero 2 lajikenimen perässä tarkoittaa myöhempää istutusta (Koe 2.).

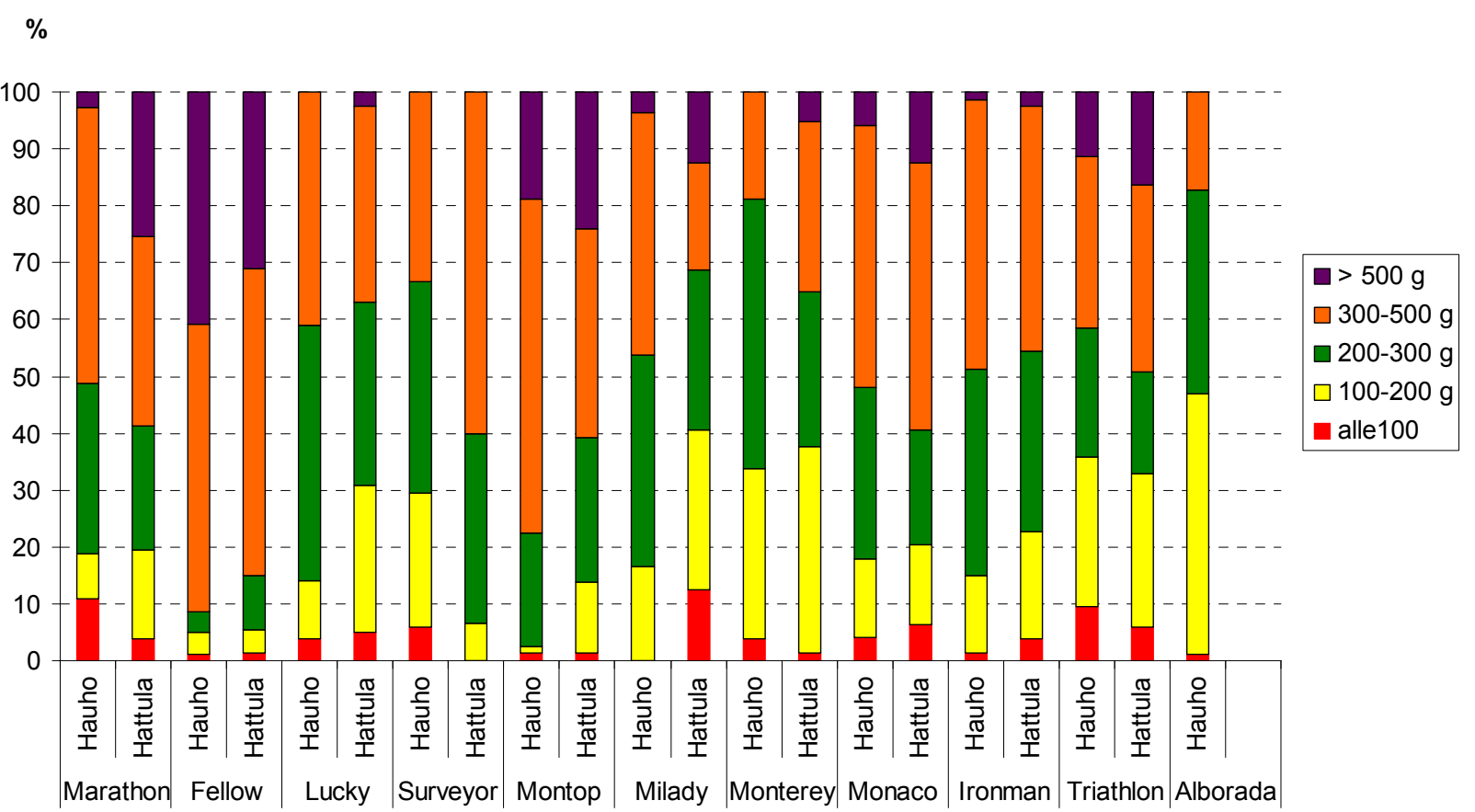

Kuvio 3. Parsakaalin kauppakelpoinen sato lajiteltuna eri painoluokkiin vuonna 2005.

Paras ulkoinen laatu oli Alboradalla, jonka varressa ei esiintynyt yhtään onttovartisuutta Hattulassa, mutta muutama onttovartinen kukinto havaittiin Hauholla, missä satoa kertyi paljon ja kasvu oli nopeaa kaikilla lajikkeilla. Laadultaan hyviä olivat myös Monterey, Iron, Lucky, Milady ja Montop. Pahasti onttovartisia olivat Triathlon, Monaco ja Surveyor. Niiden ontot varret olivat sadonkorjuuhetkellä jo muuttuneet ruskeiksi keskeltä. Triathlon näyttäisi kestävän vesitalousongelmia paremmin kuin muut lajikkeet, koska sen sato oli molemmilla koepaikoilla samaa suuruusluokkaa Hattulan möhöjuuren aiheuttamista vesitalous- 
ongelmista huolimatta. Viljelijöillä on myös samansuuntaisia kokemuksia Triahlon-lajikkeesta viime vuosilta. Muut lajikkeet näyttivät kärsivän Hattulassa enemmän veden puutteesta kasvustossa sadonkorjuuaikaan, jolloin kasvien vedentarve oli suuri helteen takia.

Vuonna 2005 aikaisimmat lajikkeet olivat parhaimpia (Kuvio 1). Fellow- lajike näytti kärsineen kuumuudesta kummallakin koepaikalla. Kaalit olivat kasvaneet suuriksi ja vain hieman kuperiksi. Lajikkeen Hauholla kasvatettujen kaalien maku arvioitiin asijantuntijaraadissa kuitenkin parhaaksi mahdolliseksi, vaikka kasvuharsoa oli käytetty pitkään ja kukinnon muoto ei ollut paras mahdollinen. 'Fellown' kukinto oli kiinteä, mutta varressa oli paljon onttoa. 'Montop' ja 'Lucky' kasvoivat samaa tahtia 'Fellown' kanssa ja valmistuivat 51-52 päivässä. Molempina koevuosina 'Montop' oli valmis 51 päivässä, mutta 'Lucky' vaati ensimmäisenä vuonna muutaman päivän lisää kasvuaikaa. 'Lucky' oli vuonna 2005 varren ja kukinnon laadultaan hyvä. Hattulassa tosin oli kukinnoissa hieman kissansilmäisyyttä. 'Montopin' varsi oli kaunis sisältä ja päältä. Lisäksi varsi oli maultaan hyvä ja hieman makea. Kukinnot olivat kuperia, joskin väri oli vihreä. Parhaana värinä on usein pidetty tumman hieman sinertävää vihreä. Sellaisia kukintoja oli vuonna 2005 vain harvoilla lajikkeilla, kuten Ironmanilla molemmilla koepaikoilla. Kokonaisuudessaan Hauholla kasvaneet kaalit olivat kuperampia kuin Hattulassa kasvatetut.

Kesän 2005 parsakaalikokeita leimasi elokuun alussa kerättyjen kaalien parempi laatu. Toisaalta aikainen Fellow-lajike näyttäisi sopivan mahdollisesti vain aivan kaikkein varhaisimpiin istutuksiin. Ainakaan rankoista keskikesän helle ja kuivuus jaksoista se ei näyttäisi pitävän, vaan kasvaa epämääräisen muotoiseksi ja onttovartiseksi. Toisaalta luomuviljelyssä hyväksi tuholaistentorjuntakeinoksi havaittu kasvuston kateharso ei vioittanut kaalien laatua. Harson alla kasvaneet kaalit olivat laadultaan hyviä, ellei parempiakin kuin ilman harsoa kasvatetut kaalit kuumuudesta huolimatta. Varmoja säänkestäviä lajikkeita voisivat olla esimerkiksi Montop ja Ironman lajikkeiden tyyppiset vaihtoehdot.

Kesä 2004 oli viileä ja sateinen, eikä kosteudesta ollut pulaa ja lämpötilat suosivat kaaleja. Kasvukauden aikana kertynyt lämpösumma vuonna 2005 oli lähellä useamman vuoden normaalia, mutta sadetta saatiin epätasaisemmin kuin vuonna 2004. Heinä-elokuun 2005 vaihteessa päättyneen lämpimän ja vähäsateisen jakson jälkeen tuli sateita. Lämmin sää jatkui ja bakteeritaudit aiheuttivat kaalin kukintoihin laatuvikoja. Arimpia bakteeritaudeille olivat 'Marathon', 'Surveyor' ja 'Triathlon'. 'Surveyorista' ei saatu kauppakelpoista satoa ollenkaan Hattulasta ja Hauhollakin lähes puolet sadosta oli pilalla (Kuvio 1).

Parsakaalin makuerot vuoden 2004 eri kasvupaikkojen välillä olivat huomattavat, vaikka viljelyjärjestelmä oli sama. Hauholla kasvatetut Milady- ja Iron-lajikkeiden parsakaalit arvioitiin erittäin hyviksi (8,5-8), vaikka arviot tehtiin kaksi viikkoa aiemmin kerätyistä kaaleista. Toisaalta Hattulassa kasvatetut samojen lajikkeiden yhtä vanhat kaalit olivat lähes kauppakelvottomia lähinnä voimakkaan, polttavan parsakaalin makunsa takia. Lisäksi verranteena oli Alborada-lajiketta pellolta, jossa oli sateisen kesän takia ollut vedenläpäisyongelmia. 'Alboradan' kaalit arvioitiin samanlaisiksi kuin Hattulan kaalit. Yhteistä näille heikoille tuloksille oli vesitalousongelmat maan tiivistymisen tai möhöjuuren takia. Tulos oli varsin yllättävä ja seuraavana vuonna arvioita tehtiin kaikista lajikekokeen lajikkeista.

Aistinvaraisissa arvioissa kauppakelpoisesta vuoden 2005 sadon elokuun alussa kerätyt lajikkeet olivat tummemman vihreitä kuin myöhemmin kerätyt lajikkeet (Kuvio 4.). Vaikka 'Fellow'-lajikkeen ulkomuoto ei ollut tavoiteltu kupera, sen oli aistinvaraisesti rakenteeltaan erittäin hyvä (Kuvio 5.). Kaikki Hauholla kasvatetut kaalit olivat rakenteeltaan erittäin hyviä. Viimeisellä arviointikerralla ne olivat myös verrannetta parempia. Maultaan heikoimpia lajikkeita olivat Milady ja Triathlon, kasvupaikkojen välillä tosin oli eroja (Kuviot 6-7). 
Väri

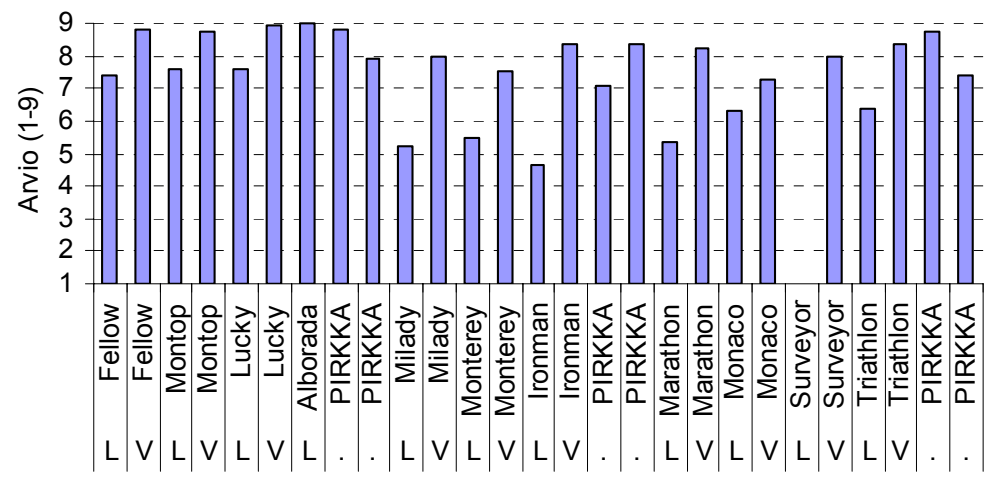

Kuva 4. Parsakaalin eri lajikkeiden väri Karlsruhen asteikolla 9-1 vuonna 2005. L tarkoittaa Hattulassa kasvatettuja kaaleja ja V Hauholla kasvatettuja kaaleja.

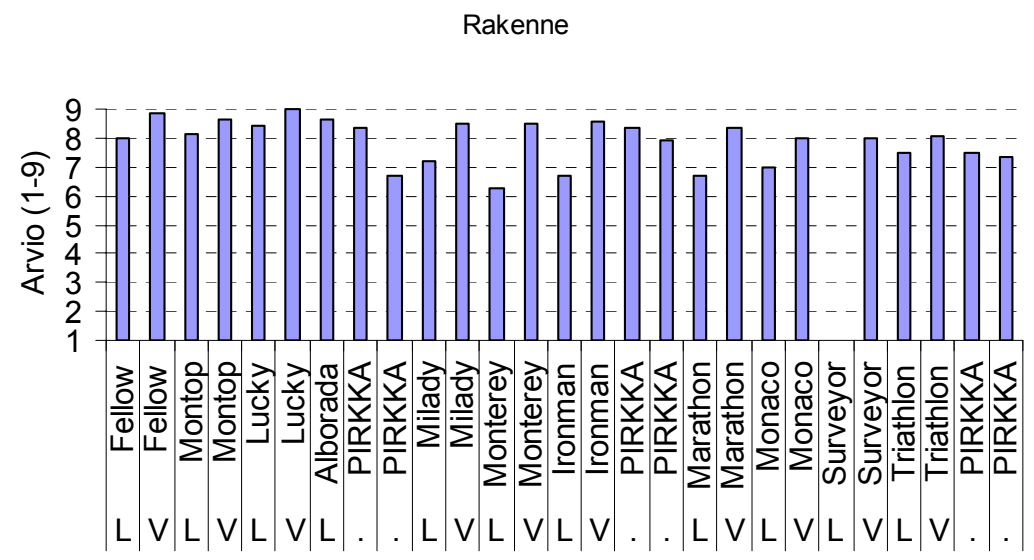

Kuva 5. Parsakaalin eri lajikkeiden rakenne Karlsruhen asteikolla 9-1 vuonna 2005. L tarkoittaa Hattulassa kasvatettuja kaaleja ja V Hauholla kasvatettuja kaaleja.

Maku raakana

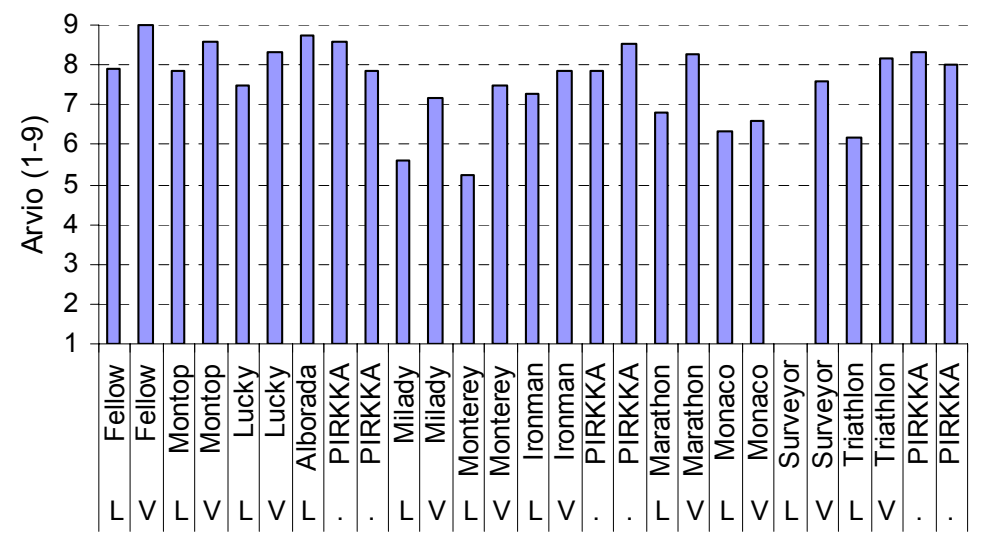

Kuva 6. Parsakaalin eri lajikkeiden maku raakana Karlsruhen asteikolla 9-1 vuonna 2005. L tarkoittaa Hattulassa kasvatettuja kaaleja ja V Hauholla kasvatettuja kaaleja. 
Maku kypsänä

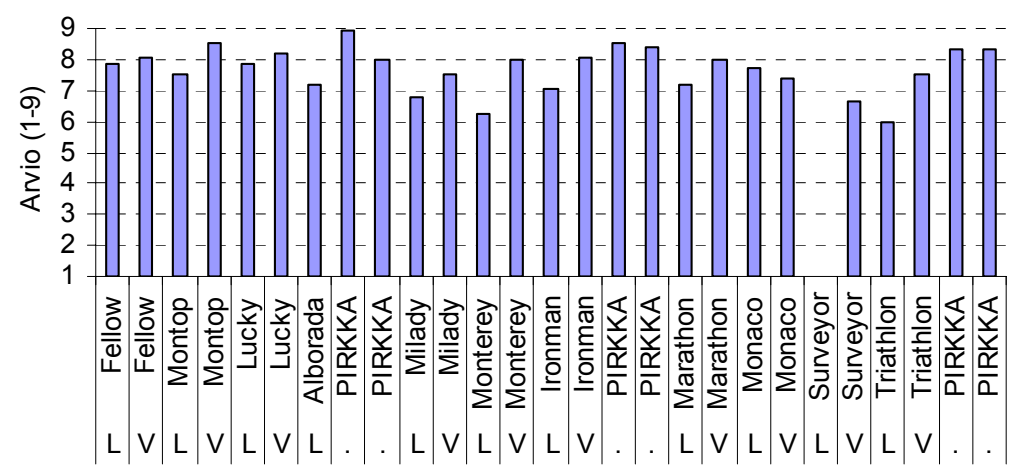

Kuva 7. Parsakaalin eri lajikkeiden maku kypsänä Karlsruhen asteikolla 9-1 vuonna 2005. L tarkoittaa Hattulassa kasvatettuja kaaleja ja V Hauholla kasvatettuja kaaleja.

\section{Johtopäätökset}

Parsakaalikokeiden tulokset osoittavat, että ammattituotantoon tarkoitetuilla lajikkeilla ja luomumenetelmillä voidaan tuottaa erinomaisia parsakaaleja niin kooltaan kuin laadultaan. Makuun ei kuitenkaan näyttäisi vaikuttavan viljelyjärjestelmä luomutuotannon eduksi, vaikka luomutuotetut kaalit olivat tässä tutkimuksessa aistinvaraisesti parempia kuin kokeen tavanomaisesti tuotetut kaalit. Tavanomaisesti tuotettu verrannekaali oli aistinvaraisesti samaa luokkaa luomukaalien kanssa. Laajemmat aistinvaraiset arvioit pitää toistaa toisena vuonna, jotta tuloksien perusteella voitaisiin laittaa toinen lajike toisen lajikkeen edelle. Toisaalta luomuviljelyssä hyväksi tuholaistentorjuntakeinoksi havaittu kasvuston kateharso ei vioittanut kaalien laatua, vaikka lämpötila nousikin harson alla korkeaksi (Voipio 2001). Harson alla kasvaneet kaalit olivat laadultaan hyviä, ellei parempiakin kuin ilman harsoa kasvatetut kaalit kuumuudesta huolimatta. Varmoja säänkestäviä lajikkeita voisivat olla esimerkiksi Montop ja Ironman lajikkeiden kaltaiset vaihtoehdot.

\section{Kirjallisuus:}

Aaltonen, M. 2005. Parsakaali -vuoden vihannes 2006. Teoksessa: Puutarhakalenteri 2006; 65, 336: 8287. Puutarhaliitto.

Voipio, I. 2001. Vihannekset, lajit, viljely ja sato. Puutarhaliiton julkaisuja 316, opas $46.351 \mathrm{~s}$. 